\title{
Bixa orellana Leaves Extract Inhibits Bradykinin-Induced Inflammation through Suppression of Nitric Oxide Production
}

\author{
Y. Yoke Keong ${ }^{a} \quad$ A.K. Arifah ${ }^{b} \quad$ S. Sukardi ${ }^{a} \quad$ A.H. Roslida ${ }^{a}$ M.N. Somchit ${ }^{a}$ \\ A. Zuraini ${ }^{a}$ \\ ${ }^{a}$ Department of Biomedical Sciences, Faculty of Medicine and Health Sciences, ${ }^{b}$ Department of Preclinical Science, \\ Faculty of Veterinary Medicine, Universiti Putra Malaysia, Serdang, Malaysia
}

\section{Key Words}

Anti-inflammatory $\cdot$ Bixa orellana $\cdot$ Bradykinin •

Vascular permeability

\begin{abstract}
Objective: The present study was conducted to assess the anti-inflammatory effect of a crude aqueous extract of Bixa orellana leaves (AEBO) and to examine the possible involvement of nitric oxide (NO) in its anti-inflammatory mechanism. Materials and Methods: The air-dried, powdered leaves were soaked in distilled water $(1: 20 \mathrm{w} / \mathrm{v})$ at $50^{\circ} \mathrm{C}$ for $24 \mathrm{~h}$ and the supernatant obtained was freeze-dried (yield $8.5 \% \mathrm{w} / \mathrm{w}$ ). The dosage was recorded as the mass of extract per kg b.w. of rats in all inflammatory assays (bradykinin-induced paw edema, peritoneal vascular permeability and NO assay). Results: Pretreatment with AEBO for 4 consecutive days exhibited significant inhibitory activity against inflammatory models, the bradykinin-induced hind paw edema model and bradykinin-induced increased peritoneal vascular permeability at both doses in dose-dependent manner. In addition, AEBO was also found to significantly suppress the production of $\mathrm{NO}$ at doses of 50 and $150 \mathrm{mg} / \mathrm{kg}$. Conclusion: This study provides scientific data to support the tradi-
\end{abstract}

\section{KARGER}

Fax +4161306 1234

E-Mail karger@karger.ch

www.karger.com (c) 2011 S. Karger AG, Basel

1011-7571/11/0202-0142\$38.00/0

Accessible online at:

www.karger.com/mpp tional use of $B$. orellana leaves in treating inflammation. Results from this study suggest that AEBO exerts anti-inflammatory effects. Part of this anti-inflammatory effect may be associated with its antibradykinin activity and may be related to a reduction of the NO production.

Copyright $\odot 2011$ S. Karger AG, Basel

\section{Introduction}

There are a number of inflammatory mediators released by cells in response to localized injury and trauma. Bradykinin, one of the peptide kinins, is generated in plasma and in a variety of peripheral tissues in response to mechanical injury or infection. It is an important inflammatory mediator, as well as an endothelium-dependent vasodilator, involved in both the initiation and progression of an inflammatory response where it sensitizes nociceptor peripheral terminals, reducing the pain threshold [1], promotes vasodilatation [2] and increases the permeability of blood vessels to the plasma component [3]. The pro-inflammatory effects of bradykinin are mediated by at least 2 receptors: the $\mathrm{B} 1$ receptor is undetectable and usually induced following tissue inflamma- 
tion and damage; on the other hand, the B2 subtype is expressed constitutively and mediates many of the actions of bradykinin [4].

Bixa orellana L or annatto, from the family Bixacea, is native to Central and South America [5] and often cultivated in countries like Brazil, Peru, Kenya, India, China, the Philippines and Malaysia. The native people of Malaysia drink a decoction of its leaves as a remedy for gastric ulcers and stomach discomforts. In Peruvian medicine, the leaves are used to treat several disorders including prostate disorders and internal inflammation $[6,7]$. The leaves are also boiled to treat colic, as well as oral and throat inflammation $[6,8,9]$. It is also one of the plants used by Rama midwives in Nicaragua for the treatment of indigestion and other digestive disorders [10] and in Guinean traditional medicine to treat infectious diseases [11].

Previous studies reported the presence of leucocyanidin, ellagic acid, apogenin, luteolin, and flavonoid bisulphates [12], while Lawrence and Hogg [13] reported the presence of ishwarane and bixaghanen in $B$. orellana leaf oil. The pharmacological action of its leaves' extract includes anticonvulsant, analgesic, antidiarrheal [14], antimicrobial [15], antileishmanial and antifungal activity [16]. In a previous study, Siti Erli Fazira et al. [17] showed that $B$. orellana plays an important role in anti-inflammatory responses induced by carragenaan. B. orellana is also able to neutralize the edema-forming effects of Bothrops asper venom [18]. In order to provide scientific support for some of these claims, the present study aimed to evaluate the anti-inflammatory effect of Bixa orellana leaves using standard experimental models. Aqueous extract of $B$. orellana (AEBO) was used to treat inflammation in animal models and the possible involvement of nitric oxide (NO) in its anti-inflammatory mechanism was examined.

\section{Materials and Methods}

\section{Experimental Animals}

The experiments were carried out using male Sprague-Dawley rats (200-250 g) housed at the animal house in the Faculty of Medicine and Health Sciences, Universiti Putra Malaysia, Selangor, Malaysia. The animals were maintained under standard laboratory conditions with access to food and water ad libitum. They were allowed a 7-day acclimatization period to adjust to the conditions. The rats were randomly selected and assigned into 4 different treatment groups of 6 rats each. Two groups of rats received AEBO at doses of 50 and $150 \mathrm{mg} / \mathrm{kg}$, while the positive group received D-Arg-L-Arg-L-pro-L-Hyp-Gly-L-(2-thienyl)Ala-L-Ser-D$1,2,3,4$,-tetrahydro-3-isoquinolinecarbonyl-L- $(2 \alpha, 3 \beta, 7 \mathrm{a} \beta)$-octahydro-1H-indole-2-carbonyl-L-Arg (HOE 140) and the negative group was treated with distilled water only. All experimental pro- cedures were carried out in strict compliance with the regulations of the Animal Care and Use Committee, Faculty of Medicine and Health Sciences, Universiti Putra Malaysia.

\section{Chemicals}

Bradykinin, Evans Blue Dye and HOE 140 were purchased from Sigma (Malaysia). Nitric/nitrate assay kit was purchased from Roche (Malaysia).

\section{Plant Material}

The fresh leaves of $B$. orellana were procured from around the Universiti Putra Malaysia, and were botanically identified and deposited at the Phytomedicinal Herbarium, Institute of Bioscience, Universiti Putra Malaysia (Voucher No. NL16, Bixa orellana).

\section{Plant Extraction}

The leaves were oven-dried at $60^{\circ} \mathrm{C}$ for 3 consecutive days and ground into powder-form with a grinder. For the preparation of aqueous extracts, the leaf powder was mixed in distilled water based on the ratio of 1 part powder to 20 parts distilled water ( $1 \mathrm{~g}$ : $20 \mathrm{ml}$ ). The mixture was placed in a water bath at $50^{\circ} \mathrm{C}$ for $24 \mathrm{~h}$ in order to allow bioactive compounds in the leaves to dissolve in distilled water. The extracts were filtered and kept at $-80^{\circ} \mathrm{C}$, then freeze-dried at high vacuum at $-40 \pm 5^{\circ} \mathrm{C}$ (yield $8.5 \%, \mathrm{w} / \mathrm{w})$. In all experiments, the dosage was recorded as the mass of extract $/ \mathrm{kg}$ b.w. of rats).

\section{Preliminary Phytochemical Analysis}

The AEBO leaves was subjected to a preliminary phytochemical screening for the presence of flavonoids, tannins, anthraquinones and saponins [19].

\section{Anti-Inflammatory Assays}

Bradykinin-Induced Paw Edema. The anti-inflammatory assay was performed according to method by Winter et al. [20]. Edema was induced in the left hind paw of the animals by subcutaneous injection of $0.1 \mathrm{ml}$ of bradykinin $(0.4 \mu \mathrm{g} / \mathrm{ml}$ in saline) into the footpad. Edema was indicated from the changes in paw volumes measured using plethysmometer (Model 7140, Ugo Basile, Italy) before and at 30, 60, 120, 180 and $240 \mathrm{~min}$, following bradylkinin injection. The AEBO (50 and $150 \mathrm{mg} / \mathrm{kg}$ ) was given orally for 4 days. Last treatment was given 60 min before bradykinin injection on the fourth day. Another group of rats was orally administered with HOE $1401 \mathrm{mg} / \mathrm{kg}$, a bradykinin antagonist, as a standard reference. The control group received distilled water.

Bradykinin-Induced NO Production. NO was measured by the method of Moshage et al. [21] using commercially available nitrite/ nitrate colorimetric kit (Roche). The sum of nitrites and nitrates was used as indicator of NO level. Following bradykinin injections $(0.4 \mu \mathrm{g} / \mathrm{ml}$ in saline) on the fourth day, inflamed rat paws were homogenized with $35 \%$ sulfosalicylic acid and then centrifuged to obtain the supernatant. Assays were carried out on the same day and the concentrations of nitrite and nitrate were measured via spectrophotometry at $540 \mathrm{~nm}$ wavelength. A standard curve was constructed using known concentrations of sodium nitrite and potassium nitrate. Values obtained from this procedure represent the NO concentrations in paw tissues, in $\mu \mathrm{M} / \mathrm{g}$ wet weight of tissue.

Bradykinin-Induced Increased Peritoneal Vascular Permeability. The changes of vascular permeability during bradykinin-induced inflammation were studied using Evan's blue dye as a de- 
Table 1. Effect of oral administration of AEBO on bradykinininduced nitric oxide production in rat paw

\begin{tabular}{lrrl}
\hline Treatment & $\begin{array}{l}\text { Dose, } \\
\mathrm{mg} / \mathrm{kg}\end{array}$ & $\begin{array}{l}\text { NO Level, } \\
\mu \mathrm{g}\end{array}$ & $\begin{array}{l}\text { Inhibi- } \\
\text { tion, \% }\end{array}$ \\
\hline Negative control (distilled water) & - & $10.22 \pm 0.33$ & - \\
HOE 140 & 1 & $7.08 \pm 0.33^{*}$ & 30.72 \\
AEBO & 50 & $8.21 \pm 0.59^{*}$ & 19.67 \\
& 150 & $5.13 \pm 0.57^{*}$ & 49.80 \\
\hline
\end{tabular}

Values are mean $\pm \operatorname{SEM}(\mathrm{n}=6) .{ }^{*} \mathrm{p}<0.05$ vs. control, 1 -way ANOVA.

Table 2. Effect of oral administration of AEBO on bradykinininduced vascular permeability in 6 rats

\begin{tabular}{lrll}
\hline Treatment & $\begin{array}{l}\text { Dose, } \\
\mathrm{mg} / \mathrm{kg}\end{array}$ & $\begin{array}{l}\text { Dye leakage, } \\
\mu \mathrm{g} / \mathrm{rat}\end{array}$ & $\begin{array}{l}\text { Inhibi- } \\
\text { tion, \% }\end{array}$ \\
\hline Negative control (distilled water) & - & $30.33 \pm 0.87$ & - \\
HOE 140 & 1 & $3.38 \pm 0.08^{*}$ & 88.87 \\
AEBO & 50 & $9.07 \pm 0.37^{*}$ & 70.08 \\
& 150 & $5.38 \pm 0.29^{*}$ & 82.27 \\
\hline
\end{tabular}

Values are mean \pm SEM. ${ }^{*} \mathrm{p}<0.05$ vs. control, 1-way ANOVA.

tector [22]. This study was based on spectrophotometric measurements of the dye that was present in peritoneal fluid indicating vascular leakage. One hour after oral administration of AEBO (50 and $150 \mathrm{mg} / \mathrm{kg}$ ), rats were injected with $5 \mathrm{ml} / \mathrm{kg}$ of $1 \%$ Evans blue solution intravenously followed by bradykinin intraperitoneally. HOE $140(1 \mathrm{mg} / \mathrm{kg})$ served as a reference drug, while animals in the control group received an equal volume of saline $(10 \mathrm{ml} / \mathrm{kg})$. The rats were sacrificed 30 min after Evan's blue injection, and its extravasations into the peritoneal cavity were measured via spectrophotometry at $610 \mathrm{~nm}$ wavelength.

\section{Statistical Analysis}

All the results were expressed as mean \pm SEM. Data were analyzed using 1-way ANOVA followed by Tukey test. $\mathrm{p}<0.05$ was considered as statistically significant.

\section{Results}

\section{Preliminary Phytochemical Data}

Results of the preliminary phytochemical analysis carried out on the crude aqueous extract indicated the presence of flavonoid, tannins, anthraquinones and saponins.

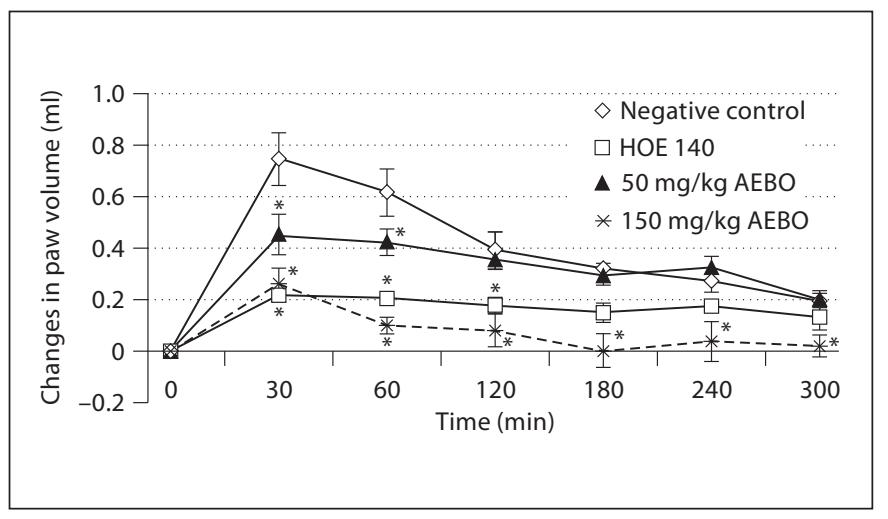

Fig. 1. Effect of aqueous extract of Bixa orellana leaves on bradykinin-induced hind paw edema in rats. ${ }^{*} \mathrm{p}<0.05$ vs. control at each time point.

\section{Effect on Bradykinin-Induced Paw Edema}

Rat paws became edematous soon after injection of bradykinin and paw volume reached a maximum after $30 \mathrm{~min}$ (fig. 1). AEBO significantly suppressed the edema formation in a dose-dependent manner. At doses of 50 and $150 \mathrm{mg} / \mathrm{kg}$, AEBO inhibited paw swelling by 39.9 and $65.6 \%$ compared to control values at $30 \mathrm{~min}$ post-injection of bradykinin, respectively. Post-hoc analysis showed significant inhibition of edema formation at the highest dose of $\mathrm{AEBO}$ at all time points, whereas at $50 \mathrm{mg} / \mathrm{kg}$, AEBO was effective at 30 and 60 min time points, respectively.

\section{Effect on Bradykinin-Induced NO Production}

After treatment with bradykinin, the NO concentration increased markedly to $10.22 \pm 0.33 \mu \mathrm{M} \cdot \mathrm{g}^{-1}(\mathrm{p}<$ $0.05)$. When rats were treated with 50 and $150 \mathrm{mg} / \mathrm{kg}$ of $\mathrm{AEBO}, \mathrm{NO}$ production was significantly suppressed in a dose-dependent manner $\left(8.21 \pm 0.59 \mu \mathrm{M} \cdot \mathrm{g}^{-1}, 5.13 \pm\right.$ $0.57 \mu \mathrm{M} \cdot \mathrm{g}^{-1}$, respectively, $\left.\mathrm{p}<0.05\right)$. Percentages of inhibition at both doses were 19.7 and $49.8 \%$, respectively (table 1).

\section{Effect on Bradykinin-Induced Increased Peritoneal Vascular Permeability}

At doses of 50 and $150 \mathrm{mg} / \mathrm{kg}$, AEBO exerted a significant effect against acute inflammation induced by bradykinin (table 2) and the inhibition of dye leakage was 70.1 and $82.3 \%$, respectively. As a positive control, HOE 140 produced a more potent anti-inflammatory effect, $88.9 \%$ inhibition of dye leakage. 


\section{Discussion}

The present study showed that AEBO, when administered orally, possessed anti-inflammatory activity. The result obtained from this study showed that at oral doses of 50 and $150 \mathrm{mg} / \mathrm{kg}$, AEBO inhibited the paw edema induced in rats by bradykinin at $30 \mathrm{~min}$ post-induction. It is well known that both tannins and flavonoids have antiinflammatory properties [23]. Thus, the anti-inflammatory activity inherent in AEBO may be related to the presence of tannins and flavonoids in the AEBO.

In the first stage of inflammatory reactions, mediators of inflammation are released following stimulation, leading to dilation of arterioles and venules and increased vascular permeability [24]. The present results also show the ability of AEBO to reduce the leakage of Evan's Blue dye into the peritoneal space during peritoneal inflammation produced by bradykinin in rats, indicating its ability to inhibit or suppress the permeability of small blood vessels. Studies by Félétou et al. [25] showed that when bradykinin is used as an inflammatory mediator to induce microvascular permeability in the hamster cheek pouch, the microvascular leakage is mediated by the B2 receptor activation but not the $\mathrm{B} 1$ receptor. This suggests that $\mathrm{B} 2$ receptors play a more important role in raising vascular permeability. The anti-inflammatory activity of AEBO may involve an inhibitory effect on bradykinin receptor or any signaling molecules further downstream to prevent vascular permeability from increasing.

Bradykinin markedly increased microvascular permeability and this action appeared to be related to the production of $\mathrm{NO}$ or a NO-containing compound [26]. Nitric oxide is an important inflammatory mediator and regulatory molecule for various physiological functions, such as neurotransmission, vasodilatation and important for host defense [27]. The NO produced by endothelial nitric oxide synthase mediates vascular relaxation, but when produced in high amounts is able to increase the vascular permeability [28]. The possible mechanism that is involved in vascular permeability suppression by AEBO was investigated through determination of $\mathrm{NO}$ level in paw fluid. From the results obtained, we can suggest that AEBO produces its anti-inflammatory activity by preserving the endothelial barrier function of the small vessels, an action largely dependent on the suppression of NO formation. Furthermore, the effect of AEBO was comparable to that of the reference drug, HOE 140 (specific antagonist for $\mathrm{B} 2$ receptor) used in this study. It has been shown that HOE 140 could decrease vascular permeability through inhibition of nitrite release [29].

\section{Conclusion}

The results of the present study showed that AEBO possesses significant anti-inflammatory activity against the acute phase of inflammation, which may be due to its antibradykinin activity. These results provide support for the traditional use of $B$. orellana leaves in inflammation, but warrant further studies to establish its therapeutic value as well as its mechanism of action.

\section{References}

1 Wang H, Tatsuro K, Fumimasa A, Brenner GJ, Nobuku I, Allchorne A, Ji RR, Woolf CJ: Bradykinin produces pain hypersensitivity by potentiating spinal cord glutamatergic synaptic transmission. J NeuroscI 2005;25: 7986-7992.

2 Huey PMW, Cenedeze MA, Pesquero JB, Silva AP, Camara S: NO: influence of bradykinin $\mathrm{B} 1$ and $\mathrm{B} 2$ receptors in the immune response triggered by renal ischemia-reperfusion injury. Int Immunopharmacol 2006; 13-14:1960-1965.

$>3$ Han ED, MacFarlane RC, Mulligan AN, Scafidi J, Davis AE: Increased vascular permeability in $\mathrm{C} 1$ inhibitor-deficient mice mediated by the bradykinin type 2 receptor. J Clin Invest 2002;109:1057-1063.

\footnotetext{
4 Ahluwalia A, Perretti M: B1 receptors as a new inflammatory target: could this $\mathrm{B}$ the 1 ? Trends Pharmacol Sci 1999;20:100-104.

5 hare CP: Indian Medicinal Plants: An Illustrated Dictionary. New York, Springer, 2007, pp 102.

6 Morton J: Atlas of Medicinal Plants of Middle American. Springfield, IL, Thomas Publishing Co., 1981, pp 572-573.

7 Sanz-Biset J, Campos-de-la-Cruz J, Epiquién-Rivera MA, Cañigueral S: A first survey on the medicinal plants of the Chazuta valley (Peruvian Amazon). J Ethnopharmacol 2008; 122:333-362.

8 Ayensu ES: Medicinal Plants of the West Indies. Algona, MI, Reference Publications, 1981, pp 54-56.

9 Honychurch PN: Caribbean wild plants and their uses. Barbados, WI, Letchworth Press, 1980, p 16.

10 Coe FG: Rama midwifery in eastern Nicaragua. J. Ethnopharmacol 2008;117:136-157.

11 Magassoubaa FB, Diallo A, Kouyaté M, Mara F, Mara O, Bangoura O, Camara A, Traoré S, Diallo AK, Zaoro M, Lamah K, Diallo S, Camara G, Traoré S, Kéita A, Camara MK, Barry R, Kéita S, Oularé K, Barry MS, Donzo M, Camara K, Toté K, Berghe DV, Totté J, Pieters L, Vlietinck AJ, Baldé AM: Ethnobotanical survey and antibacterial activity of some plants used in Guinean traditional medicine. J Ethnopharmacol 2007; 114:44-53.

12 Harbone JB: Flavonoid bisulphates and their co-occurrences with ellagic acid in the Bixaceae, Frankeniaceae and related families. Phytochemistry 1975;14:1331-1337.
} 
13 Lawrence BM, Hogg JW: Ishwarane in Bixa orellana leaf oil. Phytochemistry 1973;12: 2995.

14 Shilpi, JA, Taufiq-Ur-Rahman M, Uddin SJ, Alam MS, Sadhu SK, Seidel V: Preliminary pharmacological screening of Bixa orellana L. leaves. J Ethnopharmacol 2006;108:264271.

$\checkmark 15$ Fleischer TC, Ameade EPK, Mensah MLK, Sawer IK: Antimicrobial activity of the leaves and seeds from Bixa orellana. Fitoterapia 2002; 74:136-138.

- 16 Braga FG, Bouzada MLM, Fabri RL, Matos MO, Moreira FO, Scio E, Coimbra ES: Antileishmanial and antifungal activity of plants used in traditional medicine in Brazil. J Ethnopharmacol 2007;111:396-402.

17 Siti Erli Fazira AJ, Zuraini A, Shiran MS: Effect of Bixa orellana on carragenan induced inflammation rat. Proc 6th Nat Symp Health Science 2006:18.

-18 Nunez V, Otero R, Barona J, Saldarriaga M, Osorio RG, Fonnegra R, Jimenez SL, Diaz A, Quintana JC: Neutralization of the edemaforming, defibrinating and coagulant effects of Bothrops asper venom by extracts of plants used by healers in Colombia. Braz J Medi Biol Res 2004;37:969-977.
9 Asongalem EA, Foyet HS, Ekobo S, Dimo T, Kamtchouing P: Anti-inflammatory, lack of central analgesia and antipyretic properties of Acanthus montaus (Ness) T. Anderson. J Ethnopharmacology 2004;95:63-68.

20 Winter CA, Risley EA, Nuss GW: Carrageenan-induced oedema in hind paws of the rats as an assay for anti-inflammatory drugs. Exp Biol Med 1963;111:544-547.

21 Moshage H, Kok B, Huizenga JR: Nitrite and nitrate determination in plasma: a critical evaluation. Clin Chem 1995;41:892-896.

22 Whittle BA: The use of changes in capillary permeability in mice to distinguish between narcotic and non-narcotic analgesics. Br J Pharmacol 1964;22:264-253.

23 Feng LH, Rui LL, Huang B, Liang M: Free radical scavenging activity of extracts pre pared from fresh leaves of selected Chinese medicinal plants. Fitoterapia 2004;75:14-23.

24 Vogel HG, Vogel WH: Drug Discovery and Evaluation: Pharmacological Assays. Berlin, Springer, 1997, pp 402-403.
25 Félétou M, Bonnardel E, Canet E: Bradykinin and changes in microvascular permeability in the hamster cheek pouch: role of nitric oxide. Br J Pharmacol 1996;118: 1371-1376.

26 William GM: Role of nitric oxide in modulating permeability of hamster cheek pouch in response to adenosine $5^{\prime}$-diphosphate and bradykinin. Inflammation 1992;16:4.

27 MacMicking J, Xie QW, Nathan C: Nitric oxide and macrophage function. Ann Rev Immunol 1997; 15:323-350.

28 Fukumura, D. Xavier R, Suqiura T, Park EC, Lu N, Seliq M, Nielsen G, Taksir T, Jain RK, Seed B: Tumor induction of VEGF promoter activity in stromal cells. Cell 1998;94:715725

29 Maryanne RK, Seyedi N, Xiaoping Z, Marboe CC, Michler RE, Addonizio LJ, Kaley G, Nasjletti A, Hintze TH: Regulation of nitric oxide production in human coronary microvessels and the contribution of local kinin formation. Circulation 1996;94:44-51. 